\title{
DNA Evidence: Examining Police Officers' Knowledge of Handling Procedures in a Mid-Size Department
}

\author{
Robert C. Hauhart ${ }^{*}$ and Kimberly R. Menius \\ Department of Society and Social Justice, Saint Martin's University, 5000 Abbey Way SE, Lacey, WA 98503, \\ USA
}

\begin{abstract}
Studies of policing dominate the criminal justice literature but very few studies report empirical data regarding police handling of evidence, specifically including DNA evidence. Given that evidence handling is crucial in the investigation and prosecution of criminal offenders, this gap in the literature is surprising. The present paper addresses the quality of evidence handling in a mid-size police department in the northwest United States. Three surveys - two of officers within the department and one of state crime lab managers who test and examine evidence samples provided to them by local police departments - suggest that police offers in this mid-size city are only modestly familiar with proper evidence handling procedures, including those procedures regarding the collection, packaging, transportation and submission of possible DNA evidence.
\end{abstract}

Keywords: Evidence, evidence handling, DNA evidence, DNA evidence handling, evidence collection, crime scene procedures.

\section{INTRODUCTION}

Policing is one of three institutional foci within contemporary criminal justice but it is studies of policing that abound and dominate the pages of criminal justice journals. A quick search using Proquest Criminal Justice on December 27, 2012, for example, produced 107,534 results for "police or policing" from the $400+$ journals indexed but only 77,027 results for "corrections or prisons or jails". A related search through the same database on that date for "criminal courts" produced even fewer results: 74,470 . Given the thousands of studies of policing over the last twenty years, one would assume that virtually every aspect of policing would have been studied at length by now given the breadth and depth of the scholarly interest exhibited. In particular, one would assume that virtually all of those police investigatory techniques and practices dedicated to solving crimes would have been exhaustively examined by police scholars by the early $21^{\text {st }}$ century.

However, the truth of the matter is that many investigatory techniques, including the reliability of fieldwork procedures conducted by police officers, have seldom been subjected to rigorous scientific scrutiny. (Harris 2012:19) For example, a general search through Proquest Criminal Justice on December 27, 2012 for papers relating to "police and evidence" produced 22,632 results. Yet, remarkable as it may seem, there were few studies that can be found which

*Address correspondence to this author at the Department of Society and Social Justice, Saint Martin's University, 5000 Abbey Way SE, Lacey, WA 98503, USA; Tel: (360) 438-4525; E-mail: rhauhart@stmartin.edu investigate systematically the actual quality of police field evidence collection and evidence handling capabilities. This may be due, in part, to the emergence and reliance on crime scene technicians. The Washington State Patrol's Crime Scene Laboratory, for example, covering the state where this study was conducted, has a Crime Scene Response team of twenty-plus forensically trained staff. However, many smaller and mid-size American police departments which constitute the overwhelming majority of the $17,000+$ U.S. law enforcement agencies - do not employ forensically trained crime scene technicians. ${ }^{1}$ The consequence is that much of the physical evidence relating to crimes - including samples that may be intended for later DNA testing - must be collected by sworn officers, especially those from smaller, rural departments. Further literature searches illustrate the problem.

A complementary search of the same database on the same date for "fingerprints or fingerprinting" and a search within the (above) "police and evidence" search for "collection and preservation" produced 5127 results and 533 sources, respectively. Furthermore, a search within the "fingerprints and fingerprinting" results for "DNA" - and within that search for "police and secondary transfer" - reduced the facially relevant

\footnotetext{
${ }^{1}$ Although we do not attempt to assess the training and capability of crime scene technicians to handle evidence, including potential sources of DNA evidence, other studies that have done so conclude that there are lapses and gaps in evaluating their capability as well. Raymond, et al., 2008 (30-40\% of Australia and New Zealand crime scene examiners and laboratory technicians are estimated to not have had their skills assessed with regard to trace DNA handling and analysis as late as 2004).
} 
papers to 54. From these various searches and other similar searches not detailed here, it becomes clear that police evidence handling, while a recognized issue of concern, has apparently seldom produced systematic, empirical studies of the actual practices pursued by officers within police departments. Rather, the overwhelming preponderance of published articles on police evidence handling simply discuss, and recite, the importance of written policies, specific practices or recommended protocols that are simply recorded in manuals or posted on training websites. Are officers sufficiently knowledgeable and well-trained to conduct crime scene evidence gathering when called upon to do so? Do they actually know their own policies? Do officers know how to handle potential sources of DNA evidence? There has been little investigation of these issues.

More specifically, although scientific progress in the analysis of DNA has developed rapidly over the last twenty years, there appear to be few studies of police officers' DNA knowledge base and consequent capability for conducting proper DNA sample evidence collection. Representative articles focus frequently on reiterating the general importance of proper evidence procedures (Barbeau 2003; Geberth 2003) or describing contemporary practices for proper evidence preservation (Weiss and Davis 2003; Geberth 2003). Articles on DNA evidence generally discuss the development and use of DNA science to examine ever more obscure sources of DNA (Korpelainan and Virtanen 2003) or focus on technical aspects of laboratory DNA analysis. Finally, the proficiency of crime lab testing and issues that impact it have been the subject of study (Peterson and Markham 1995a; Peterson and Markham 1995b; Gill and Kirkham 2004). Seldom found, however, are empirical investigations of the handling practices police departments actually pursue with respect to collecting evidence for DNA testing or studies of officers' understanding of proper protocols for handling DNA evidence samples. Police procedures for the handling of suspects and evidence may have come a long way since passage of the Metropolitan Police Act (1829) and Robert Peel's development of the first government supported urban police force. Yet based on the paucity of published research it is an open question whether American police officers are capable of properly handling DNA evidence samples in a scientifically sound manner when called upon to do so. This is the lacunae in contemporary American police research that our study was intended to address.

\section{BACKGROUND SUMMARY}

Extensive citation is not required to suggest that physical evidence has come to play an increasingly important role in police investigations over the last one hundred years. In the late twentieth century, advances in pure science and technology rapidly contributed to the ability to develop DNA evidence. However, while the science and technology now exist to support DNA evidence collection and analysis, police departments may - or may not - have developed and implemented policies and practices to properly handle and process evidence intended for DNA testing. Moreover, even if departments have developed such policies and protocols there is the question of whether officers have developed the knowledge base necessary to handle trace evidence collection when required to do so. This is true even though the problem of DNA evidence contamination is well known (Ladd, et al. 1999; Bellefeuille, et al. 2003; Scherczinger, et al. 1999; Phipps \& Petricevic 2007).

The Zenith ${ }^{2}$ Police Department, Zenith, Washington, like any other contemporary department, is required to collect, preserve and test various types of physical evidence, including DNA samples. Like most modern American police departments in the twenty-first century, the Zenith Police Department (ZPD) has some familiarity with the use of DNA evidence and some policies and procedures in place. At the same time, the Department's executives believed - as late as 2012 that many of the Department's existing policies and practices could be improved. This project arose when the junior author was invited to examine the Department's evidence handling policies and procedures. However, the studies reported here were designed, executed, and controlled solely by the authors. $^{3}$

The Zenith Police Department (ZPD) was formed in 1967 . The City of Zenith has grown rather rapidly from 7,650 residents in 1967 to 40,000 plus residents today. ZPD had three (3) commissioned officers in 1967; by 2012 there were 52. The police department is comprised of a Patrol Division and Support Services Division. As of this writing he former is comprised of 30 officers, six sergeants, two lieutenants, and a patrol

\footnotetext{
${ }^{2}$ Zenith is a fictitious name for a city in Washington and its police department of the same name. The authors are grateful to the Zenith, WA Police Department for their cooperation and support of this study.

${ }^{3}$ A separate report, 102 pages long, was prepared for the ZPD summarizing the forensic basis for DNA testing and evidence handling and offering specific recommendations for that department.
} 
commander. This division is responsible for responding to all 911 and non-emergency calls, writing reports, enforcing traffic laws, investigating collisions, and enforcing criminal laws within the city limits. There are also specialized traffic units, a K-9 unit, and School Resource Officers within this division. The latter division consists of the Detective Division, Crime Prevention, and the Records Division. Along with the two core divisions there are also Community Services Officers and volunteers that maintain and support the ZPD. In short, the Zenith Police Department is a traditional American police department in a small, suburban city at the dawn of the twenty-first century. ${ }^{4}$ Like many another department its size, the ZPD does not employ any commissioned or civilian trained evidence technicians. ZPD, like other county and municipal police departments in Washington, does have the ability to request assistance from the approximately 20+ trained evidence technicians statewide employed with the Washington State Highway Patrol's Crime Labs.

Typically, all Washington state sworn officers are assumed to have taken an introductory course in the collection and use of evidence including evidence that may be subject to DNA testing. In Washington, local probationary police officers must attend the Basic Law Enforcement Academy (BLEA) at the Washington State Criminal Justice Training Commission (WSCJTC) before they can become fully sworn officers. (Members of the Washington State Patrol attend their own accredited academy in Shelton, WA.) The BLEA training consists of a total of 720 hours (WSCJTC, 2012) which includes instructional sessions on: Criminal Law and Procedures; Traffic Enforcement; Cultural Awareness; Communication Skills; EVOC; Firearms; Crisis Intervention; Patrol Procedures; Criminal Investigation and Defensive Tactics (WSCJTC, 2012a). An executive at the BLEA stated that while there is no dedicated session and mandated curriculum specifically for DNA evidence handling ${ }^{5}$,

\footnotetext{
${ }^{4}$ According to the Uniform Crime Report (UCR) for Zenith, WA violent crimes are far outnumbered by property crimes. Between 2006 and 2010 , there were a total of 452 UCR violent crimes reported compared to the total of 8,172 reported UCR property crimes. Although violent crimes are less often reported to law enforcement, the reports suggest that property crimes are far more common than violent crimes in Zenith (City of Zenith, "Crime information," n.d.). ${ }^{5}$ Zenith is not distinctive in this regard as law enforcement academies nationwide exhibit a lack of emphasis on DNA evidence training for new recruits. A 2005 survey of state and local law enforcement academies, by the Bureau of Justice Statistics reported the average basic training program to be 761 hours (Reaves, 2009, p. 1). Most academies emphasized physical fitness with training in firearms and self-defense tactics. Other prevalent training topics ranged from basic first aid to criminal and constitutional law (Reaves, 2009, pp. 4,6). Although the BJS reports an increase of community policing and terrorism-related training, DNA evidence training is not mentioned anywhere in the report as a separate area of instruction. (Reaves, 2009, p. 7).
}

"During evidence handling [sessions] there is mention of DNA evidence, taking clothing, body fluids, blood, and transfer of DNA on clothing" (personal communication, March 5, 2012). Furthermore, the same executive states that DNA should also be covered under the Criminal Investigation session as well although there is no specific curricula for DNA evidence training outside the existing modules (personal communication, March 5, 2012). ${ }^{6}$

In addition to the required basic training offered by the Washington police academy, Zenith police officers can acquire training and practical experience in evidence collection through the series of policies and procedures established by the ZPD. Procedures and protocols regarding evidence are outlined in two documents: the Zenith Police Policy Manual and the Officer's Packaging Manual. Chapter 11.0 of the Policy Manual is the evidence section. This chapter states the general duties of patrol officers regarding evidence, provides guidelines on what to do with different types of evidence, and explains property room procedures, including procedures on how to release, store or dispose of property. The property/evidence room has a well-established security system, maintains restricted access, and requires standard "chain of custody" paperwork procedures.

Chapter 11.1 of the Policy Manual outlines specific procedures for evidence collection and also recites standard guidance regarding crime scenes (i.e., the responding officer should secure the crime scene with barrier tape and remove all unnecessary individuals while initiating a log for those who enter the scene, and so forth). With respect to evidence collection, the manual states that evidence to be submitted is to be sealed in a package either by heat or evidence tape with the initials and date to overlap. The manual describes when items should be packaged separately and how the package should be labeled. The manual further states that evidence needs to be submitted by the end of the submitting officer's shift but the responsibility to send items to the crime lab is that of the evidence room employee. The section then briefly outlines procedures for perishable evidence including how to collect and package it.

The Officer's Packaging Manual supplements the above guidance and provides general instructions on

\footnotetext{
${ }^{6}$ The WSCJTC does provide post academy and advanced training opportunities that occasionally offer some training in DNA related topics, among others. These courses, however, have limitations as to who can attend None are required.
} 
what to do with property items of different sizes or those considered a biohazard. It also lists what information is needed to log the item and provides descriptions of how to seal and tag evidence of different types, proper plastic packaging and labeling, and procedures for handling wet items. Chapter 12.3 of the Policy Manual provides guidance on wearing selfprotective clothing and clothing specific to evidence handling, mainly masks and gloves. According to one ZPD employee, "...We do not typically use masks and special clothing. In sexual assault cases the rape kits are normally done by nurses. Gloves are sufficient." (personal communication, June 8, 2011). In neither document is there specific guidance as to how to handle possible DNA evidence samples as distinguished from physical evidence generally.

Basic academy training and departmental guidance aside, ZPD and other Washington police officers may or may not actually possess sufficient working knowledge to properly collect, handle, and refer evidentiary samples for testing. This is due, in part, to the rapid acceleration in scientific knowledge and testing procedures in recent years as well as to the nature of DNA and samples that may possess testable DNA material. Our study was designed to assess officers' knowledge of handling possible DNA evidence and consisted of three surveys. The first survey presented officers a series of questions asking for selfassessment in their knowledge of proper DNA evidence handling procedures. Twenty six ZPD (26) officers (22 male, 4 female) from the force of 52 officers completed Survey I. The second survey consisted of a ten question quiz regarding proper DNA handling procedures. Questions for the quiz were developed using the Washington State Patrol Forensic Services Guide and National Institute of Justice (NIJ) Journal under the guidance of the Lab Supervisor for the WSP Crime Lab in Tacoma, WA, the state's third busiest crime lab. Nineteen (19) officers (5 detectives, 14 officers) completed this survey. The results suggest that Zenith Police Department uniformed officers seldom handled evidence likely to be tested for DNA. Further, results showed many lacked the knowledge and training necessary to collect and process DNA evidence properly. A third survey of Washington State Patrol Crime Laboratory supervisors was conducted to limit potential bias arising from the small scope of the ZPD research. This approach of using multiple methods to investigate a social phenomenon from different data sources is termed triangulation (Cresswell 1994:174; Denzin 1978) and is particularly suitable for exploratory studies like ours.

\section{REVIEW OF THE LITERATURE}

\section{Risk and Reliability in Forensic Use of DNA}

According to Krimsky and Simoncelli (2011), "Although DNA is revered as the 'gold standard' of forensic science, not all DNA is the same" (p. 276). This problem arises in part due to the quality and quantity of DNA source material that is collected. For example, degradation is an important issue because "DNA, like any other chemicals, will break down over time. The rate of degradation depends on the type of cells (saliva, blood, semen, skin), as well as the conditions under which the samples are stored" (Krimsky \& Simoncelli, 2011, p. 276). A great deal of the potential utility of DNA evidence for criminal justice purposes also depends on where the DNA sample is collected; "...for example, a DNA sample taken from a cigarette butt on the street where a crime was committed is less likely to have come from the perpetrator than DNA extracted from a vaginal swab of a rape victim" (Krimsky \& Simoncelli, 2011, p. 277). Thus, as far as reliability and probative value is concerned, "DNA evidence presented in a case is only as good as the DNA found at the crime scene" (Krimsky \& Simoncelli, 2011, p. 277) and provided to a laboratory in testable condition.

The inferences required by factors related to the crime scene are multiplied by other issues specific to DNA analysis. For example, "false positives can and do occur in forensic DNA analysis. They can happen because of error, contamination, interpretation of the output of DNA analyzers, and chance profile matches that can be expected in a sufficiently large population" (Krimsky \& Simoncelli, 2011, p. 277). Additional factors that can affect the accuracy of DNA evidence include the amount of "...care with which it is collected, labeled, and transported; the standards and qualitycontrol procedures of laboratories performing the DNA profile analysis; and the interpretation of the DNA analyzer data, including whether a partial profile or a mixed profiled is obtained"(Krimsky \& Simoncelli, 2011, p. 277). In short, while DNA evidence offers the prospect of identification arising from forensic procedures, DNA evidence also harbors many possible opportunities for degraded, contaminated, or otherwise tainted or unusable results.

One example of this potential is well known within the field. In the early days of DNA analysis, "masking" by a typically larger amount of material from a victim often obscured any results that might be obtained 
regarding the perpetrator's DNA. For rape cases, this was solved by the development of a process called differential extraction based on the differences in cell thickness between sperm cells and skin cells. According to Brandon L. Garrett (2011):

This biology explains why DNA testing can be such powerful evidence of either guilt or innocence in stranger rape cases. This also explains why DNA has been used far less often in other kinds of far more common criminal cases, such as assaults, robberies, drug possession cases, or misdemeanor case that receive no trial. In such cases it may be harder to rule out contamination of the evidence, since other people aside from the victim and the culprit may have been present at the scene or had a reason to be in contact with the evidence. (pp. 218-219)

Thus, the issue of adventitious transfer of DNA material prior to a crime event creates as much of a potential problem as post-crime contamination. Both forms of transfer loom large in discussions regarding the collection and preservation of possible DNA evidence samples.

\section{DNA Knowledge and Training of Law Enforcement Personnel}

As David Harris (2012:163) observes criminal cases that are based on DNA evidence share one common, irrefutable feature: they all depend on the availability of testable evidence. Without tangible, intact evidence from the crime scene to test, it is obvious that DNA testing cannot proceed. This rather obvious proposition, when coupled with the reality that in many cases it is still sworn police officers - rather than specially trained crime scene technicians - who collect the physical evidence that will be the subject of later testing, suggests that officers' knowledge of the factors that bear on proper DNA sample handling is important in procuring usable DNA evidence. Still, there seems to have been little research to assess police officers' knowledge of current scientific knowledge and corresponding evidence collection protocols for potential DNA bearing samples. The following studies are representative.

A 2007 survey of 2,250 state and local U.S. law enforcement agencies concluded "...law enforcement personnel across all levels of agencies require improved training on the benefits and use of forensic analysis" (Strom et al., 2009, p. 4-5). The authors noted that, "law enforcement agencies vary considerably in their procedures for processing, analyzing, and submitting forensic evidence" (Strom et al., 2009, p.xiv). Specifically, Strom and his collaborators found that mid- to small sized police departments demonstrated less familiarity with proper procedures and hence required more training to meet professional standards than larger departments. (Strom et al., 2009, p. xiv). Overall, "results from the survey support the notion that some U.S. law enforcement agencies continue to have only a limited understanding of the full benefits of forensic evidence and a mindset that forensic evidence is beneficial mainly for prosecuting crimes..."(Strom et al., 2009, p. 4-4).

A study by Lambert et al. (2003) shed further light on the institutional environment of American policing with respect to evidence collection generally. The authors developed a random sample of 340 Michigan law enforcement agencies and obtained 140 survey responses. They found that "seventy-eight percent of respondents agreed that knowledge of forensic science was important..."(pp. 67,72).However they also found, "about half of the law enforcement agencies have no assigned officers or unit responsible for the collection of crime scene evidence" (Lambert et al., 2003, p. 75). Among the agencies that do not have assigned officers or units, the majority of evidence was collected by the first responding officer. Furthermore, as in many jurisdictions, the state's crime laboratories are typically utilized to analyze the evidence but do not always provide trained technicians for collection (Lambert et al., 2003, p. 75). Despite the fact that a majority of agencies reported forensic science training for their personnel, DNA evidence knowledge compared to other types of evidence was rated low in importance by respondents (Lambert et al., 2003, pp. 76,77). The authors provide two possible explanations. "First, these areas tend to be handled by specially trained personnel who tend to have graduate degrees in the hard sciences" (Lambert et al., 2003, p. 78). Second, "...many current law enforcement officials have little background in these areas themselves and therefore may not fully understand their importance in a criminal investigation" (Lambert, et al., 2003, p. 78). The authors conclude, generally, that there is a clear need for law enforcement personnel to be more knowledgeable about forensic science. (Lambert, et al., 2003, p. 80)

Aydogdu (2009) conducted a study in an attempt to understand the perceptions of law enforcement officials 
regarding forensic informational needs of patrol officers. The author obtained the cooperation of the Louisville Metro Police Department (LMPD) and developed a survey instrument for distribution to officers. Ultimately, he obtained 184 usable responses out of his 956 member survey population. The author was interested, in part, in whether the perceptions differed between officers of various ranks and the Department administrators. (pp. 48, 56). Aydogdu found "...no statistically significant differences among the perceptions of patrol officers, their supervisors and administrators, crime scene technicians, and detectives about forensic science information needs of patrol officers" (2009, p. 66).Training topics considered significant by at least $80 \%$ of all respondents, regardless of rank, included, "Interviewing techniques, evidence collection, crime scene documentation, firearm evidence, latent and fingerprint evidence, and blood evidence..." (Aydogdu, 2009, p. 66). In addition, "Death investigation, DNA evidence, document evidence, electronically recorded evidence, trace evidence, biological fluid evidence, arson and explosive evidence, and impression evidence were rated by more than half of the respondents as either important or very important” (Aydogdu, 2009, pp. 66-67). Yet, like so much of the existing research, Aydogdu does not go further. He does not attempt to gather empirical evidence regarding LMPD officers' knowledge and capability of proper crime scene protocols and DNA evidence handling.

Knecht \& Whitman (2008), on the other hand, evaluated the DNA knowledge of victim services providers. Although this is one of the few studies we located which focused on possession of DNA knowledge by professional respondents, only seven percent $(7 \%)$ of those respondents were law enforcement (Knecht \& Whitman, 2008, p. 3). Knecht and Whitman reported that "eighty-five percent of respondents cited a need for additional training on DNA among victim-serving professionals..."(Knecht \& Whitman, 2008, p. 10). Aside from professional colleagues, "a remarkable $45 \%$ of respondents cited television as one of their sources of information, and $44 \%$ indicated that they receive information from popular print media such as newspapers and magazines"(Knecht \& Whitman, 2008, p. 7). Furthermore, only half of the respondents cited training as a source of information about DNA. (Knecht \& Whitman, 2008, p. 7). The survey results suggested that the majority of respondents did not lack an understanding of the basics of DNA but rather lacked knowledge in more advanced sub-topical areas (Knecht \& Whitman, 2008, p. 10). However, among the top concerns mentioned by respondents were issues related to: the frequency of DNA collection and usage in criminal cases; inadequacy of collection and storage practices; and the increasing backlogs in un-analyzed evidence samples. ${ }^{7}$ (Knecht \& Whitman, 2008, p. 9).

\section{STUDY I}

\section{Participants}

Data was collected from 26 commissioned officers from the Zenith PD in Zenith, Washington. A notice was sent out to all 52 commissioned police officers at the department by official email inviting them to participate. Among the 26 respondents, 22 were male and 4 (15.4 $\%)$ were female. The department has an $11.5 \%$ population of female officers (6/52). Respondents were between the ages of $26-37$ and $42-50$; the largest number were between $42-45$ years of age (see Figure 1). The average age of all commissioned officers for ZPD is 39. The largest group of respondents had more than 20 years of police experience (see Figure 2). Seven (7) respondents had law enforcement experience that was not with the ZPD. $69.2 \%$ of the participants had achieved at least a Bachelor's degree (see Figure 3).

\section{Materials and Procedure}

The survey was developed to collect data on several discrete topics regarding the department and individual officers. These included the department's DNA policies, procedures; and evidence room and an officer self-assessment of general DNA knowledge. The survey consisted of fifteen questions. The first five questions requested information regarding the respondent's gender, age, police experience, and education. The next six questions asked officers to offer opinions regarding DNA evidence and a

\footnotetext{
${ }^{7}$ After the initial survey, the National Center for Victims of Crime conducted a multidisciplinary focus group at its national conference to explore some of the issues raised by the survey and to assess the DNA-related training needs of the field generally (Knecht \& Whitman, 2008, p. 11). There were 20 attendees, five of whom were law enforcement officers (Knecht \& Whitman, 2008, p. 11). Overall, conference participants confirmed the survey results by stating they derived most of their information regarding DNA from what they called 'informal sources' rather than formal training. (Knecht \& Whitman, 2008, p. 12). Priority DNA training topics recognized by the law enforcement attendees included: expanded use of DNA to solve more crimes; the proper collection and storage of DNA; DNA evidence as it related to specific crimes; and DNA use in cold cases and exonerations. (Knecht \& Whitman, 2008, p. 15). In summary, "...the group agreed with the survey respondents that more training is needed for all disciplines, and that, currently, there is no good training delivery system for those professionals who want more information about DNA evidence"(Knecht \& Whitman, 2008, p. 14)
} 


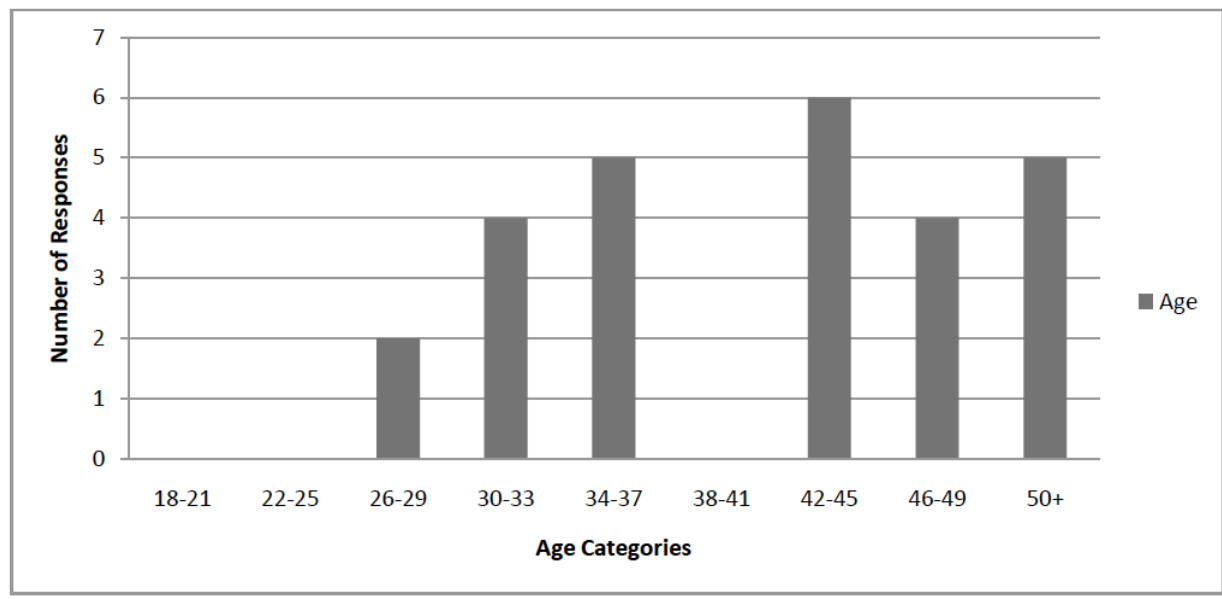

Figure 1: Survey I Participant Age Distribution.

ZenithPolice Department age distribution of survey I participants.

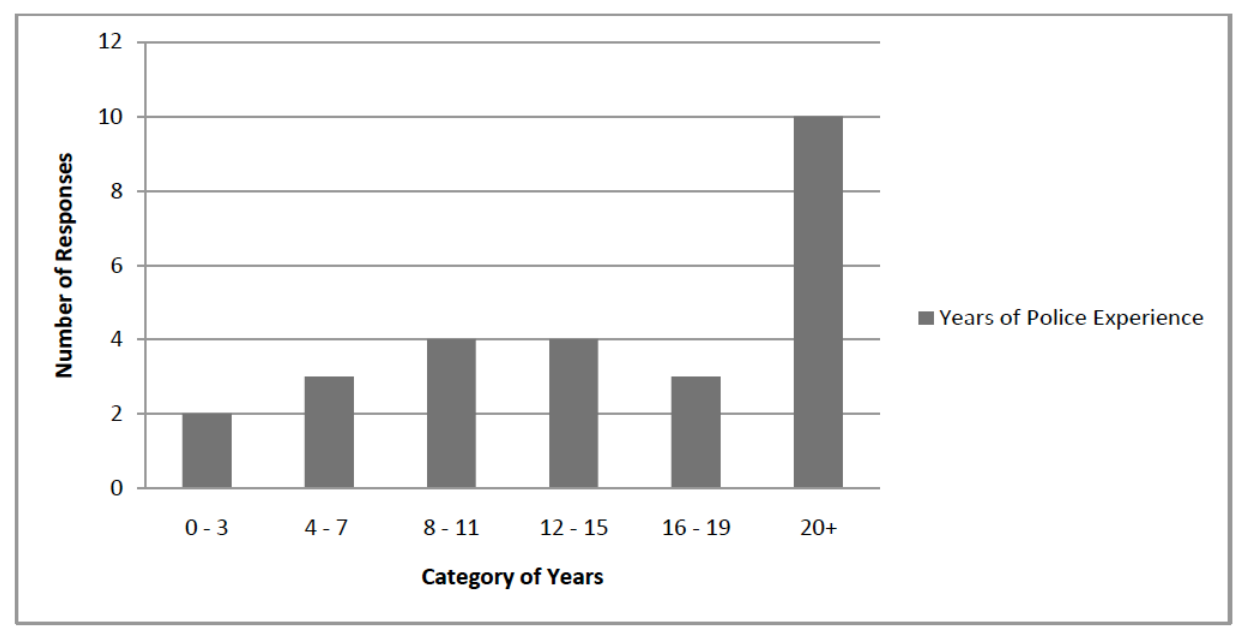

Figure 2: Survey I Police Experience Distribution.

Zenith Police Department police experience distribution of survey I participants.

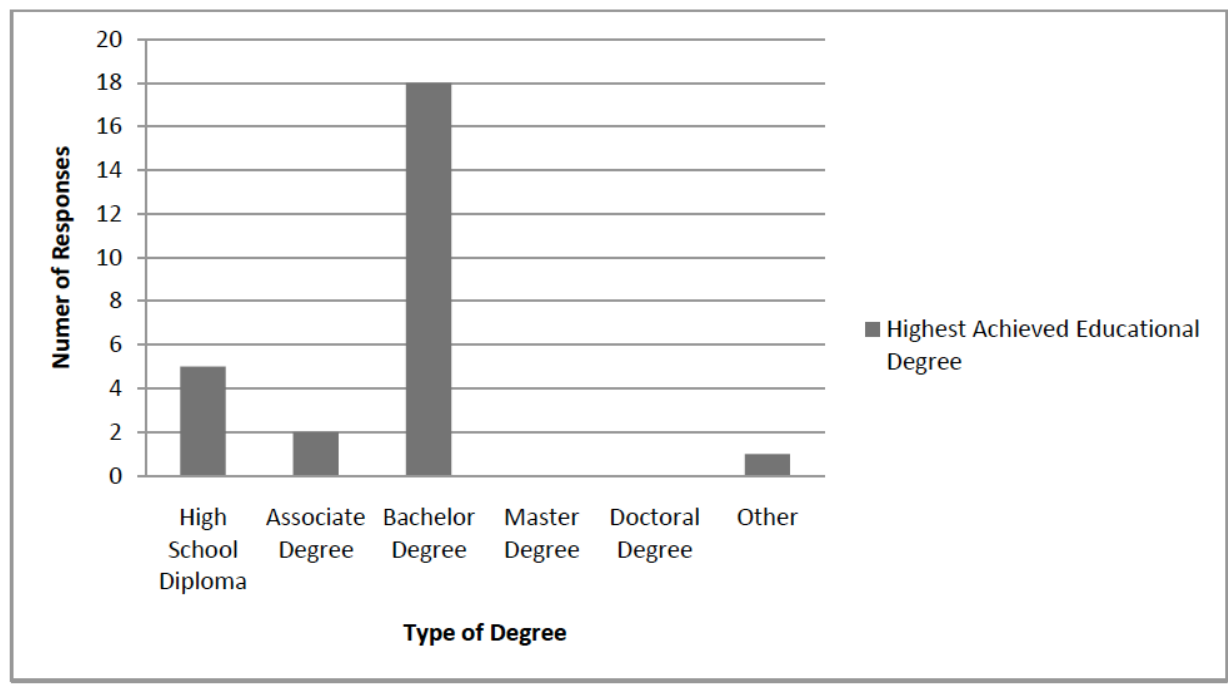

Figure 3: Survey I Participant Education Distribution.

Distribution of highest achieved educational degree by the Zenith Police Department survey I participants. 
self-assessment of their own knowledge of DNA evidence. The next three asked for a rating of the respondent's satisfaction with regard to the department's DNA policies. The final question asked the officers to describe any changes they might want to see in departmental DNA policies and procedures.

The survey was posted on a website that hosts surveys (www.SurveyMonkey.com). With administrative authorization, the link to the survey and an informed consent notice was sent out to all ZPD commissioned officers. The informed consent advised the participants about the nature of the study and how the results would be used. Officers were also advised that the survey was completely anonymous and that they had a right to refuse participation and/or exit the survey at any time. The participants could then accept or decline the informed consent. ${ }^{8}$

\section{Results}

Of the 26 respondents, $65.4 \%$ stated DNA was very important to them as a police officer; $34.6 \%$ rated it as somewhat important. A substantial majority of the officers $(80.8 \%)$ said that they rarely interacted with DNA evidence on a daily basis; $11.5 \%$ reported never having to interact with DNA evidence and $7.7 \%$ said 'sometimes'. Officers rated their knowledge of identifying DNA sources from good to poor: $34.6 \%$ said good, $19.2 \%$ said average, $27 \%$ said fair, and $19.2 \%$ said poor. $34.6 \%$ of those responding described themselves as having average knowledge regarding practices related to the preservation of DNA evidence; $30.8 \%$ reported their knowledge as poor; $23.1 \%$ as good; and $11.5 \%$ as fair.

With respect to their knowledge of the collection of DNA samples $30.8 \%$ described themselves as average, $26.9 \%$ for both fair and poor, and $15.4 \%$ as good. When asked to rate their knowledge of the ZPD's DNA evidence policies and procedures, 53.9\% responded "average". Good and fair each had a 15.4\% response and poor received an $11.5 \%$ response (see Figure 4). $61.5 \%$ reported neutral satisfaction with respect to the amount of DNA evidence funding given to the department; $23.1 \%$ said they were somewhat dissatisfied; $11.5 \%$ as very dissatisfied; and $3.8 \%$ as somewhat satisfied.

${ }^{8}$ Consistent with contemporary ethical research requirements, the authors sought and received approval from the University's Institutional Review Board regarding administration of the survey and these procedures.
Officers were asked about their satisfaction with departmental training opportunities offered regarding DNA evidence. $38.5 \%$ responded as neutral. $30.8 \%$ said they were somewhat dissatisfied, $23.1 \%$ as very dissatisfied, and $3.8 \%$ both for very satisfied and somewhat satisfied. $65.4 \%$ responded as neutral when asked about their satisfaction towards the ZPD's current DNA evidence policies and procedures. 15.4\% responded as somewhat satisfied, $11.5 \%$ as somewhat dissatisfied, and $3.85 \%$ as both very dissatisfied and very satisfied (see Figure 5).

In the last question, officers were asked to comment on any changes they would want to see in Zenith PD policies and procedures regarding DNA evidence or the evidence room. Only five (5) officers - out of $26-$ responded. One officer said, "We should have more training (perhaps during mandatory training periods) on how to identify and collect potential items of DNA evidence". A second stated, "I think Departmentprovided training in the identification, collection, and preservation of DNA evidence for officers should be provided to all officers. Not just those who specifically request to go to specialized training." Other comments involved wanting more specialized training and encouraging more collection of DNA evidence.

\section{Discussion}

Results revealed that the majority of participants felt DNA evidence was important to them as a police officer. However, most said they rarely interacted with DNA on a daily basis. For interpretive purposes of the DNA knowledge questions, responses were divided into three groups: average; responses for "Excellent" and "Good" were treated as above average; responses for "Fair" and "Poor" as below average. Although the highest number of responses for a single response category for the knowledge of identifying DNA sources was "Good," a majority of the responses fell below average. In addition, a majority of respondents - by their own assessment - fell below average in their knowledge of how to preserve and collect DNA. Most officers rated their knowledge of the ZPD's DNA evidence policies and procedures as "average".

The largest percentage of officers rated their satisfaction with the amount of DNA evidence funding given to the department as "neutral". However, a majority of officers responded as "dissatisfied" (either somewhat dissatisfied or very dissatisfied). Officers also felt dissatisfied with the number of DNA evidence training opportunities. The current policies and 


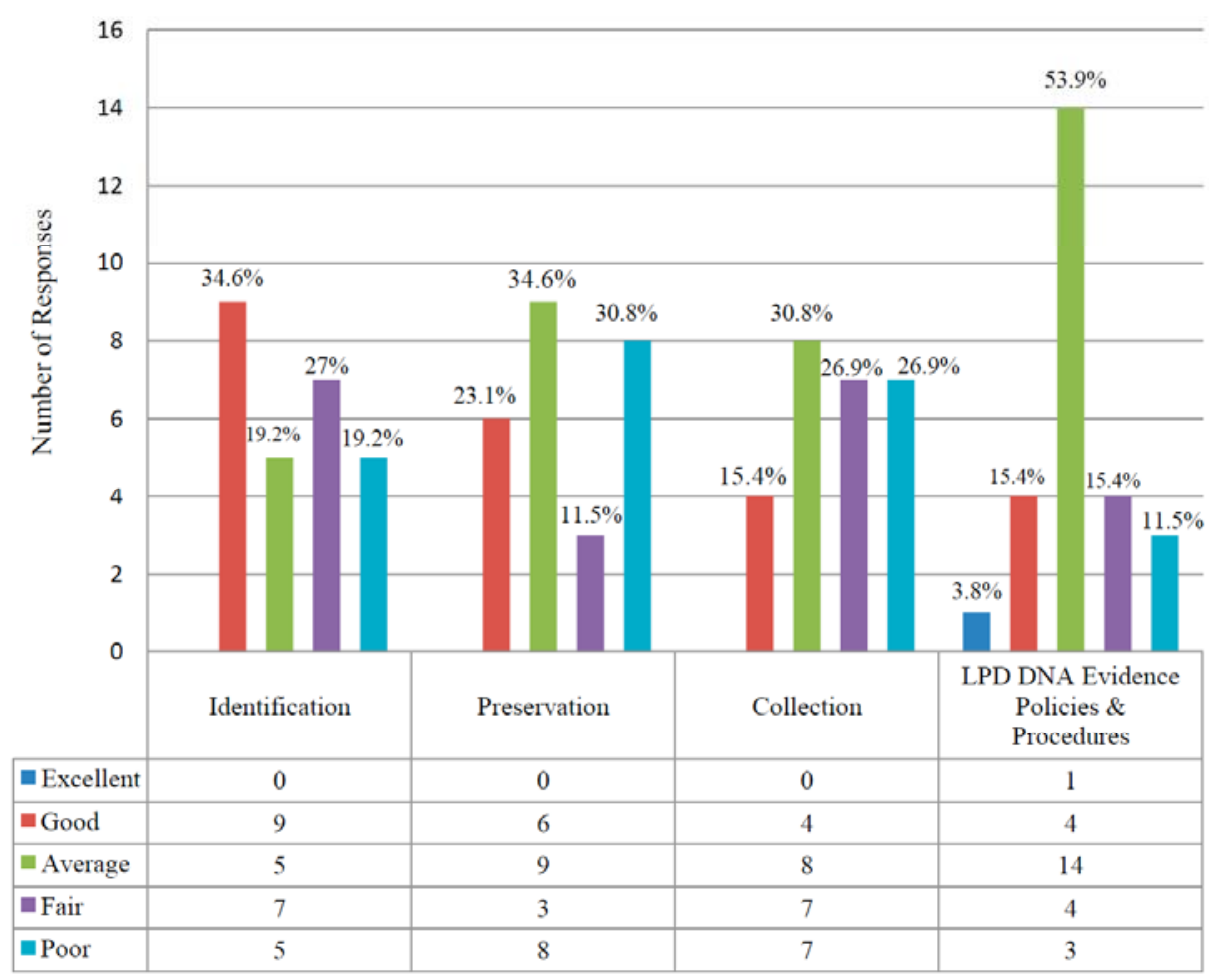

Figure 4: Survey I Distribution of Knowledge.

Analysis of survey I answers regarding knowledge of DNA evidence.

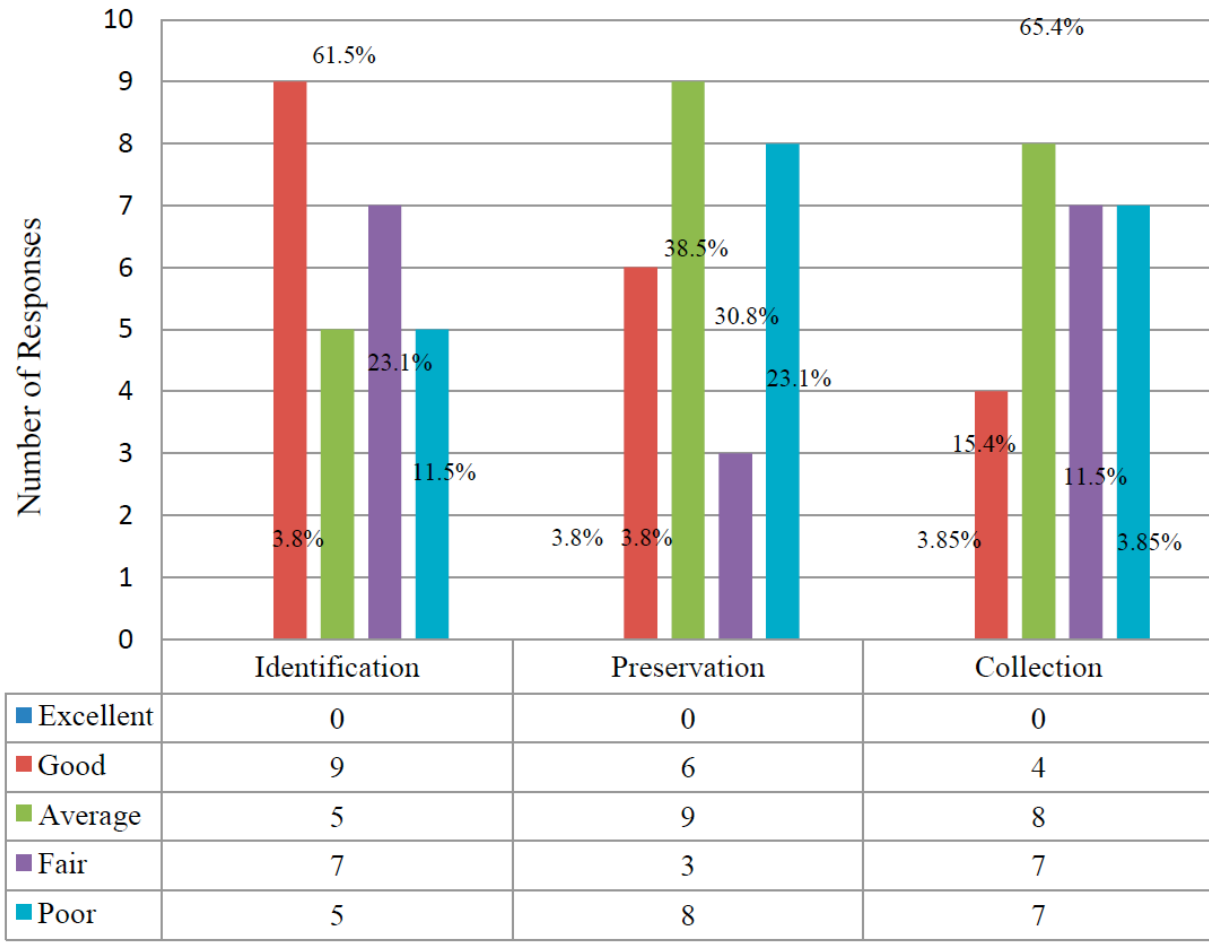

Figure 5: Survey I Distribution of Satisfaction.

Analysis of survey I responses regarding the ZPD DNA evidence funding, training opportunities, and DNA evidence policies and procedures.

procedures regarding DNA evidence received an overwhelming response of "Neutral."
While officers stated they felt "neutral" regarding the current policies and procedures for DNA evidence 
within the department, and claimed to have an average understanding of them, the latter did not seem supported by personal observation and informal interviews conducted by the junior investigator. For example, many officers could not explain to the junior researcher what the ZPD evidence manuals stated. A majority also responded neutral to the amount of DNA evidence funding given to the department. Yet many of the officers do not know the budget amount currently allocated for DNA collection, handling, and testing thereby making their assessment questionable. Contrary to the expressed view that DNA evidence is important, ZPD officers' responses suggest their knowledge of DNA evidence handling procedures and the department's evidence policies and procedures is, by their own estimate, below average.

\section{STUDY II}

\section{Participants}

Data was collected from 19 commissioned ZPD officers from a voluntary and anonymous survey. The procedures followed by Study II were identical to those described for Survey I. The survey only distinguished between detectives and all other commissioned officers. Among the 19 respondents, five (5) were detectives and 14 were other commissioned officers.

\section{Materials and Procedure}

In order to better assess the working knowledge of DNA evidence among the ZPD officers and detectives, a second survey was developed to collect objective data. Unlike the first survey which relied on a selfassessment of the officers' knowledge, this survey consisted of questions developed from the Washington State Patrol (WSP) Forensic Services Guide and NIJ Journal (Washington State Patrol, 2010; National Institute of Justice, 1999).

The survey consisted of ten (10) DNA evidence questions regarding essential knowledge. The first two questions asked about where DNA can be found and whether all biological evidence is visible and can be seen with the naked eye. The next four questions asked about issues regarding contamination and proper evidence handling. The last four questions asked about the preservation of DNA evidence, degradation, and packaging considerations. An answer key was used to determine the score for each survey respondent.

\section{Results}

The average score for the detectives (5) was $72 \%$. The highest score was an $80 \%$ and lowest $60 \%$ (see Figure 6). The average score from the other commissioned officers (14) was $66 \%$; the highest score was $90 \%$ and lowest $40 \%$ (see Figure 7 ).

In the first identification question regarding where DNA can be found, only two (2) - of the five detectives selected all the correct answers. All five detectives selected saliva as a DNA source. $80 \%$ selected perspiration, muscle, fingernails, and feces. Only $60 \%$ selected urine. Responses from the other officers showed that four (4) - out of 14 - selected all the correct DNA sources. Fourteen (14) selected saliva as a source but only $86 \%$ selected fingernails, $79 \%$ for muscle and urine, $64 \%$ for perspiration, and $57 \%$ for feces. When asked whether all DNA evidence is visible to the naked eye, all participants of both groups selected the correct answer.

Under collection, the participants were asked whether biological evidence could be potentially contaminated by a person sneezing or coughing near evidence. All nineteen respondents selected the correct answer. When asked what types of behavior should be avoided near DNA evidence, only two (2) - out of 5 detectives and three (3) - out of 14 - other commissioned officers selected all the correct answers. The detectives all selected smoking and eating as behavior to be avoided but $80 \%$ selected drinking and only $40 \%$ selected talking on the phone. The other commissioned officers all selected eating and drinking as behaviors to avoid. 93\% selected smoking but only $21 \%$ selected talking on the phone. The participants were then asked whether biological evidence is best collected as an entire item; $60 \%$ of detectives and $64 \%$ of the other commissioned officers got the correct answer. The last collection question asked the participants whether gloves should be changed frequently and between the handling of different evidence items. All detective participants selected the correct answer but only $93 \%$ of commissioned officers did so.

In discussing preservation, the participants were asked about the type of materials that should be used to package potential biological evidence. Four (4) - of the 5-detectives and five (5) - of the 14 - other commissioned officers chose the correct answer. One participant from the detectives selected both the plastic bag and plastic container (two incorrect answers). 


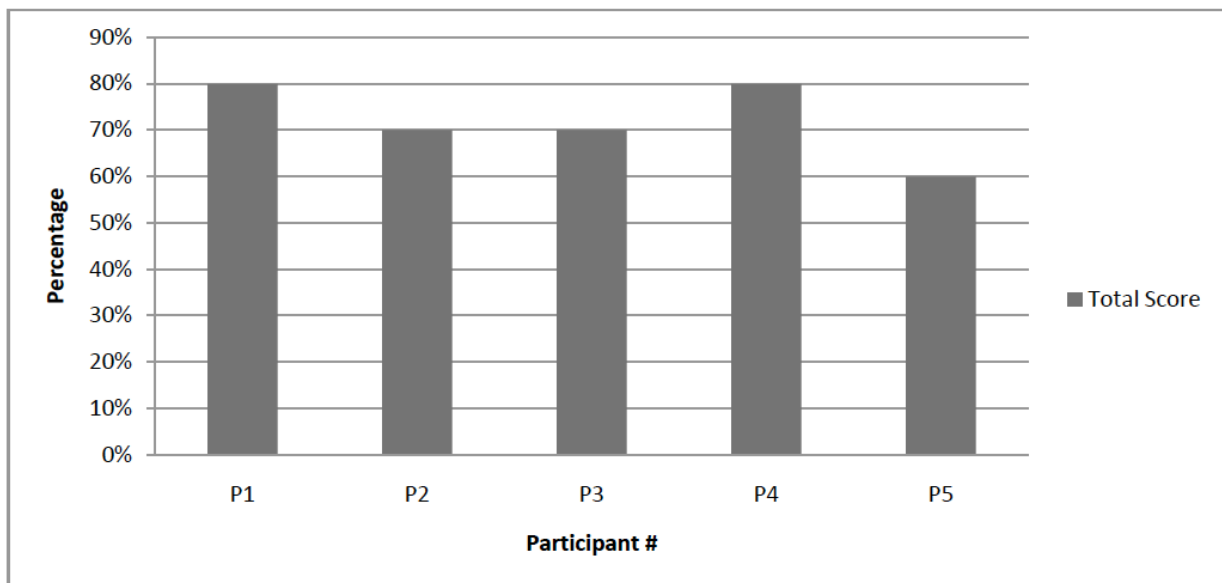

Figure 6: Distribution of Survey II Scores (Detectives).

Distribution of overall survey II scores by detective participants.

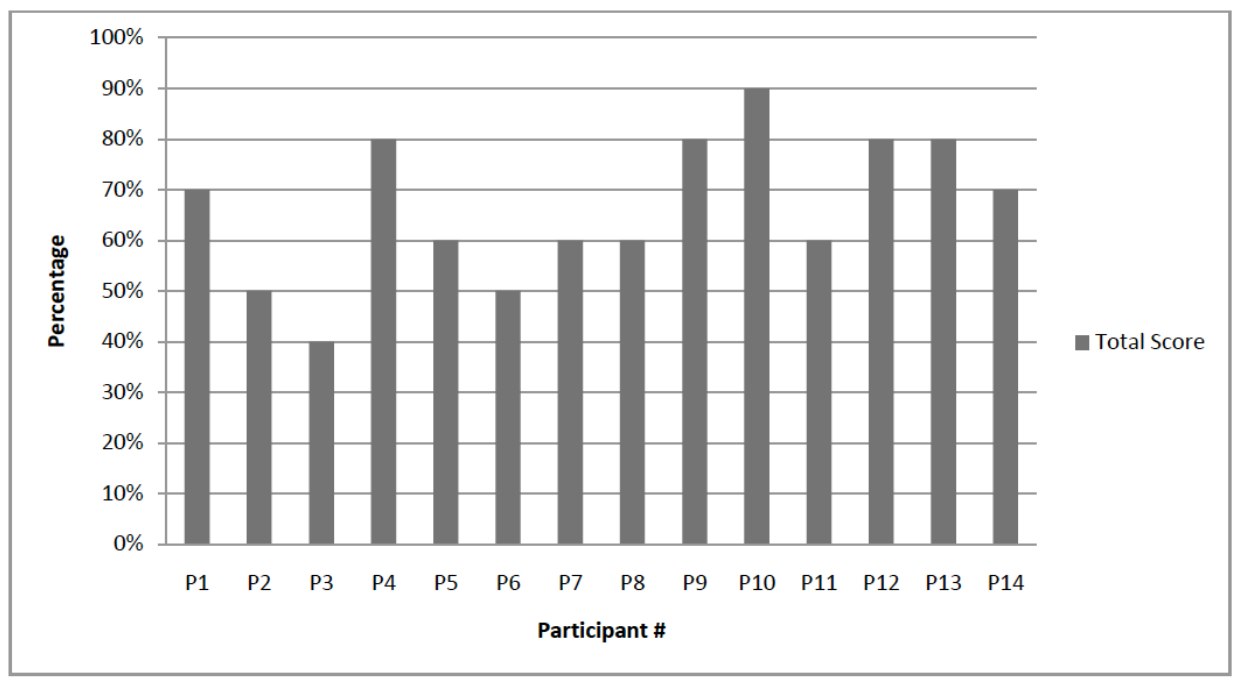

Figure 7: Distribution of Survey II Results (Other Commissioned Officers).

Distribution of overall survey II scores by all other commissioned officer participants.

Among the other commissioned officers, 21\% selected the plastic bag, 64\% selected the paper bag, $43 \%$ selected the cardboard box, 50\% selected the envelope, and $36 \%$ selected the plastic container. When asked whether sunlight or warm conditions could potentially damage DNA evidence, four (4) - of the 5 detectives and thirteen (13) - of the 14 - other commissioned officers selected the correct answer. When asked whether evidence items, stains, and swabs could be dried with the use of heat, four (4) - of the 5 - detectives selected the correct answer. Only eleven (11) - out of 14 - other commissioned officers chose the correct answer. The final question asked which potential DNA evidence items required special consideration when packaging. Two (2) - of the 5 detectives and eight (8) - of the 14 - other commissioned officers answered correctly. $80 \%$ of detectives and $86 \%$ of other commissioned officers felt bottles/containers with liquids required special consideration. The sample selected condoms only $86 \%$ of the time. $40 \%$ of the detectives selected metal objects/rocks as requiring special handling and $50 \%$ of the other officers agreed.

\section{Discussion}

The study revealed that many of the detectives and commissioned officers lacked a sufficient degree of DNA evidence knowledge to meet contemporary scientific standards. The overall averages of $72 \%$ for detectives and $66 \%$ for commissioned officers suggest that perhaps as many as one third of sworn ZPD officers are insufficiently trained in handling DNA evidence. Detectives may have scored higher than the 
other commissioned officers due to their additional experience and training but the difference is slight. Though some of the percentage rates were considered satisfactory in response to some questions, one cannot conclude officers generally possessed sufficient working knowledge of DNA evidence issues.

An examination of the state of current forensic science with respect to issues surrounding DNA contamination and secondary transfer illustrates the gap between ZPD officers' knowledge of basic DNA issues and the DNA evidence handling knowledge required. It is now widely agreed that DNA can be transferred among handled objects. (Walton, et al., 2011) This is true whether officers wear gloves or not since the DNA transferred need not be their own. Moreover, laboratory studies have identified many of the factors that facilitate - or retard - DNA transfer, including the substrates that will accept transfer most readily. Thus, studies have shown that with respect to blood and saliva there is a lower likelihood of transfer to paper than plastic. (Wiegand, et al., 2010) Moreover, with respect to saliva, research suggests that the presence of moisture on the receiving surface enhances the likelihood of transfer, especially to a "smooth" surface such as plastic. (Warshauer, et al., 2012) While smooth, non-porous surfaces have been found to be the best receiving surfaces for "wet" DNA transfer, a recent study suggests that human skin exposed to saliva can retain testable samples for up to 96 hours. (Kenna, et al. 2011) These findings suggest that ZPD officers' apparent willingness to talk on cell phones in the presence of potential DNA evidence samples - spewing saliva as they do so - is contraindicated by existing scientific knowledge.

Recent research regarding skin cell transfer also bears on evidence collection practices where DNA is concerned. Thus, ZPD and other American police officers are typically aware that fingerprint analysis may later be performed on crime scene objects, especially those with firm, non-porous surfaces. They may be less aware that non-porous surfaces - like plastic and highly finished wood - are also best for receiving sufficient skin cell transfers to permit DNA testing. (Daly 2012; Goray 2010a; Goray 2010b) Moreover, skin cell transfer is facilitated by "friction". (Goray 2010a; Goray 2010b) Thus, when an object or sample from a crime scene is handled, even with gloves, skin cell DNA will be transferred [to an officers' glove, for example] or simply some portion of the deposit destroyed if there is "friction" in the handling of the item. Since both the amount and the location of any
DNA can be critical in retrieving a usable profile, it is apparent that "normal" evidence collection procedures simply do not meet the contemporary standards for DNA evidence sample collection. Perhaps the most compelling studies with respect to DNA evidence collection and preservation practices are those which suggest that significant quantities of DNA can be transferred from crime scene samples to the packaging used to collect evidence. (Goray 2012) Moreover, the same study results show that it is quite common for DNA to be transferred from one location on a sample to other locations on the same sample in the course of packaging. (Goray 2012) Either form of transfer has the potential to defeat the use of the DNA tested sample for evidentiary purposes. These authors conclude that their results suggest that one of the most urgent needs from a scientific point of view is to develop improved packaging practices that can limit the potential for these very common DNA transfer problems using today's standard procedures.

\section{STUDY III}

While studying officers' self-rated or actual knowledge is one approach to assessing police officer knowledge of contemporary DNA evidence handling techniques, a second approach could entail asking the recipients of DNA evidence submitted from the field crime laboratories - about the quality of DNA evidence samples they receive. In our third study, data was collected from laboratory managers/supervisors of the five multi-service crime laboratories operated by the Washington State Patrol (WSP). These crime laboratories are located in Tacoma, Seattle, Vancouver, Spokane, and Marysville. ${ }^{9}$ All five respondents from each laboratory held a Bachelor's degree or higher. All degrees were either from a scientific discipline or related to forensic science. Respondents each had over 12years of experience working for the WSP laboratory; some had additional experience gained from another laboratory.

\section{Materials and Procedures}

A survey consisting of 15 questions was used to collect data concerning the quality of DNA evidence submitted to the laboratories. The survey was sent by email to each of the five WSP laboratory divisions requesting participation along with an attached consent form.

${ }^{9}$ WSP laboratories located in Kennewick and Tumwater were not included in the study due to their limited-services. 
The first four questions inquired about the forensic lab manager and/or supervisors' educational background and experience. Each was then asked his or her opinion about the overall quality of submitted DNA evidence that they received from WA law enforcement agencies. Participants were specifically asked how often that DNA evidence was unsuitable for testing.

The participants were then asked to list the most commonly collected DNA evidence sources submitted and asked to estimate the frequency with which each of the sources was mishandled or submitted in deteriorated or degraded condition. Each was asked his or her opinion on whether the number and quality of training opportunities offered to WA law enforcement officers in regards to DNA evidence was adequate. Respondents then were asked to rate the overall knowledge they believed WA law enforcement officers possessed in the identification, collection, preservation, and packaging of DNA evidence.

Participants were next asked to list specific mistakes commonly made in the areas of collection, preservation, and packaging. They were also asked to estimate the frequency that potential DNA evidence is contaminated. The final question examined whether they noticed differences in the quality of submitted DNA evidence depending on the size of the submitting law enforcement agency. Participants were then offered the opportunity to make any recommendations or changes they would suggest to improve law enforcement officers' knowledge and handling of DNA evidence.

\section{Results}

Four (4) - of the five - respondents stated the quality of submitted DNA evidence from law enforcement agencies was generally good. Only the Seattle division respondent stated it was average. The frequency that the evidence is determined unsuitable for DNA testing varied. Three (3) divisions said it happened rarely while the Spokane lab said "regularly" and Tacoma lab said "sometimes". The most commonly collected DNA evidence sources included semen, blood, cellular/touch, and saliva. The frequency of semen being mishandled and submitted in deteriorated or degraded condition was rare according to all labs. The two (2) divisions that listed saliva as a common source also stated it was rare. The quality of blood submitted, however, varied; two (2) laboratories stated it sometimes was poor quality while the remaining three (3) said it was a rare occurrence.
Within the three (3) laboratories that listed cellular/touch, two (2) said the sample was degraded sometimes while the third lab said it was rare.

With respect to DNA evidence identification, four (4) - of the five - lab supervisors responded it was good. Only one laboratory considered it average. The same findings applied to officers' knowledge of proper collection. In regards to preservation, three (3) laboratories considered it good while two (2) responded it was average. Lastly, in packaging, three (3) laboratories stated it was average and two (2) responded it was good. Four (4) - of the five respondents said potential DNA evidence is rarely contaminated.

The errors that Washington officers tend to make in the collection of DNA evidence varied. The Vancouver lab listed four common mistakes: talking over evidence as a means of contamination, not calling in the crime scene response team for assistance, incorrectly using screening tools, and not collecting the appropriate reference or elimination samples. The Spokane division also noted four common errors: the distribution of samples over too many swabs, over-emphasis on touch DNA as being probative, not wearing personal protective equipment, and compromising between latent print and DNA evidence collection that leads to poor results. At the Seattle division, the incorrect item number or description of evidence were the main concerns. Tacoma noted the agency swabbing an item instead of sending the item in to be swabbed by the lab was a common problem. Marysville identified three problem issues: the lack of protective gear, attempts to collect swabs themselves instead of sending the item in for swabbing, and not realizing what types of evidence may be useful for DNA testing and therefore not collecting it. Common issues in regards to preservation among the laboratories included inadequate drying of wet items, placing evidence in materials such as plastic rather than paper, and not maintaining certain evidence in cool temperatures. Issues surrounding packaging were far more extensive. The common answers included insufficient or incorrect labeling, packaging items in too small a package, and improper packaging for the type of evidence submitted.

Four (4) - of the five laboratory divisions stated that there are differences in the quality of submitted DNA evidence depending on the size of the law enforcement agency. The Spokane division was the only respondent to say there was no difference and stated "This is possibly due to the fact that while larger agencies may 
have a larger knowledge base, the smaller agencies are more likely to call and ask for guidance from the lab prior to collection and/or submission of DNA evidence" (personal communication, March 6, 2012). Vancouver stated, "Generally the larger agencies have more experience submitting DNA evidence and have a better handle on what to collect and how to submit (personal communication, March 6, 2012). In addition, "...sometimes the smaller agencies are more willing to call and get advice when something unusual comes up - it can be the culture of the agency rather than the size that matters" (personal communication, March 6, 2012). Seattle stated, "The smaller agencies seem to need a little more assistance when prioritizing evidence for examination and when packaging evidence; however, they do tend to ask for help more often than do the larger agencies" (personal communication, March 20, 2012). The Tacoma respondent stated, "I think that medium sized agencies probably do the best. Small agencies may realize they don't know what to do and call asking for advice - which is good - or just do what they think is best (may not be the best). Large agencies may think they know what to do, and have their own forensics technicians, and they may not really be up to date on the best practices (they think they know so they don't ask). Medium sized agencies I think we tend to have more contact with. It seems like it varies more by geography than size as far as getting what we want evidence-wise" (personal communication, February 13, 2012). Marysville added "The larger agencies tend to have detective units dedicated to specific types of crimes. They also deal with a larger number of crimes. They often have more resources to allocate toward training opportunities for their detectives and as each detective spends more time in the unit, they successfully develop their knowledge base and become experts in investigationwhich includes the recognition, collection and preservation of all kinds of evidence" (personal communication, March 19, 2012).

When asked about the adequacy of the number and quality of training opportunities offered to WA law enforcement officers only two (2) - out of the fivelaboratories responded that it was adequate. The Vancouver division stated, "Our laboratory continually offers free training to agencies, answers questions posed by law enforcement officers regularly by phone, and supplies written guides for evidence handling and collection. However, not all agencies or individuals take full advantage of the training available to them" (personal communication, March 6, 2012). The
Marysville division also stated that they also made efforts to provide various training sessions (personal communication, March 19, 2012). On the other hand, the Spokane division claimed "Officers that receive training from sources other than WSP often seem to be getting poor or incorrect information, or information that contradicts what would be provided by WSP. When training is offered by WSP it is often poorly attended and 'on the street' officers do not seem to be getting the information they need, but they are the ones that need it the most" (personal communication, March 6, 2012). Seattle division added, "We do not have the resources to provide regular, periodic training to all agencies in our service area. We do the best with the resources that are available to us" (personal communication, March 20, 2012). The Tacoma division responded, "We could do more to educate our agencies on the best ways to collect, preserve, and avoid contamination of DNA evidence. However, this is a balancing act between going out to do these regularly and staying in the lab to process cases. I would say that generally we get well collected and preserved DNA from our agencies. I do not think we have a significant problem. That also plays into the balancing act" (personal communication, February 13, 2012).

As far as recommendations from the laboratory divisions to improve law enforcement officers' knowledge and handling of DNA evidence, there seems to be a general consensus. First, there needs to be more training. Some agree that the WSP labs could conduct more outreach but stated they need more time and resources to provide such in-service training. Second, respondents recommended that agencies make an added effort to ensure officers attend when training is offered. One laboratory division even suggested that the training be a part of the promotion criteria for detectives or a required training event for newly hired evidence technicians. Lab employees also suggested a tour of the lab facility and opportunity to observe certain demonstrations. Finally, laboratories emphasize that law enforcement agencies should call and ask for guidance rather than risking the chance of doing something incorrectly.

\section{Discussion}

While in general the lab divisions state the quality of submitted evidence was adequate and the frequency of evidence being mishandled and submitted as degraded or deteriorated is rare, the specific errors cited seem to replicate our Survey I and II findings. The majority opinion that training offered to officers in Washington 
was inadequate also affirms the necessity of increased instruction in the various components of DNA evidence.

The lack of knowledge regarding the probative value or potential of specific evidence supports the findings of Lambert et al. (2003), specifically including the incorrect usage of forensic tools, lack of protective gear, and contaminating behavior. Other common errors - including not understanding the appropriate samples needed for collection in a crime or not following laboratory established guidelines - also suggest more training is needed. Many of the concerns relating to preservation identified by the laboratories reflect common issues raised by our surveys of the ZPD.

There are indications that the size of a submitting agency and quality of evidence submitted are related but our mixed results suggest more research is needed on this relationship. Factors that may bear on this issue include the amount of resources available for staffing and budget and the willingness of agencies asking for assistance. Our results generally confirm the findings of Strom \& Hickman (2010) and Strom et al. (2009), regarding mid- to small sized police agencies.

In addition to more training, some suggest that training be offered especially for those who are most likely to be working around such evidence (i.e. detectives or evidence technicians). As the research from the ZPD revealed, detectives do not necessarily possess substantially more knowledge of DNA evidence than patrol officers. This suggestion may also apply to evidence technicians whose position is a "filter" between the law enforcement officers and laboratories.

\section{LIMITATIONS TO THE STUDY}

Although our data suggests areas of concern with respect to officers' knowledge of proper DNA evidence handling, it is important to note that there were several limitations to our research. First, in the initial survey, the data was collected from only 26 participants in a single mid-size police department. Though this number constitutes half of the commissioned officers at ZPD it is still a small sample. Secondly, because there were only 26 participants, some of the responses did not result in a clear direction and the limited category responses were not statistically reliable. The survey also did not differentiate between the patrol officers and all other officers. Moreover, the word "neutral" could have been considered confusing to some participants for certain questions. Those who selected this answer either did not know enough to give an opinion or they merely didn't have an opinion. Thirdly, given that many of the officers have a limited amount of time to respond to emails respondents may have rushed through the survey and not carefully addressed each question. Lastly, even though the survey was anonymous, there is always a possibility for deception and or lack of seriousness in responding. This is especially true for some who may have experienced concern over some form of repercussion from the upper management.

In the second survey, there was also a small sample taken from the same single mid-size department. Although the survey did differentiate between detectives and all other commissioned officers, there were only 19 respondents. This number is slightly over a third of the sworn officers but may still not be representative as the respondents were selfselected. Unlike the initial survey, the participants were rated by their actual knowledge and not by selfassessment. This approach offered a better measure of the actual DNA evidence knowledge possessed by respondents but suffered the same limitations regarding truthfulness, seriousness, and time.

The survey with the WSP laboratories did not possess as many limitations. All five laboratories surveyed voluntarily responded. One of the main limitations of this study was due to respondents' variable responses to open-ended questions.

\section{CONCLUSION}

DNA evidence has come a long way over the past years and it plays an important role in the criminal justice system. With better technology and enhanced understanding, DNA evidence can increasingly aid in suspect identification. Today, DNA evidence is not only used for suspect identification but also missing person identification, human remains identification, and postconviction cases. However, as many recent cases relying on DNA analysis have shown, failed evidence remains a significant problem in our justice system leading to convictions of the innocent among other miscarriages of justice. DNA evidence is not immune from this danger. If law enforcement wishes to successfully use DNA evidence our study suggests that officer knowledge of DNA evidence handling must be improved, particularly within small departments where trained evidence technicians are not routinely available. This will require additional training for law enforcement officers, a better policy manual governing evidence 
collection at crime scenes, and some degree of periodic proficiency testing or evaluation of officers' knowledge of proper handling procedures.

\section{REFERENCES}

Aydogdu, E. 2009. Forensic Science Information Needs of Patrol Officers: The Perceptions of the Patrol Officers, Their Supervisors and Administrators, Detectives, and Crime Scene Technicians. Louisville, Kentucky: Spalding University.

Barbeau, Janet. 2003. "Evidence and Property Control." Law and Order, 51(8):96-99.

Bellefeuille, Julie, Kathy Bowen, Paula Dixon, Janet Harriman, et al. 2003. "Crime Scene DNA Contamination: Research and Practical Considerations." Journal of Forensic Identification, 53(6):729-34

City of Zenith, WA. (n.d.). Police Department. Retrieved June 13, 2011: $\quad$ http://www.ci.zenith.wa.us/city-government/citydepartments/police-department/about-us

Cresswell, John W. 1994. Research Design: Qualitative and Quantitative Approaches. Thousand Oaks, CA: Sage Publications.

Daly, D.J., C. Murphy, and S. D. McDermott. 2012. "The Transfer of Touch DNA from Hands to Glass, Fabric, and Wood". Forensic Science International: Genetics, 6(1):41-46. http://dx.doi.org/10.1016/j.fsigen.2010.12.016

Denzin, Norman K. 1978. The Research Act. New York: McGraw-Hill.

Federal Bureau of Investigation. 2007. Handbook of forensic services. Retrieved June 1, 2011, from Federal Bureau of Investigation: http://www.fbi.gov/about-us/lab/handbook-offorensic-services-pdf

Federal Bureau of Investigation. 2010. Crime in the United States 2010. Retrieved February 28, 2012, from Uniform Crime Reports: http://www.fbi.gov/about-us/cjis/ucr/crime-in-theu.s/2010/crime-in-the-u.s.-2010/property-crime

Garrett, B. 2011. Convicting the innocent: Where criminal prosecutions go wrong. Cambridge, MA: Harvard University Press.

http://dx.doi.org/10.4159/harvard.9780674060982

Geberth, V. 2003. "Physical Evidence". Law and Order, 51(7):103.

Gill, P. \& Kirkham, A. 2004. "Development of a Simulation Model to Assess the Impact of Contamination in Casework Using STR's". J. Forensic Science, 49(3):1-7. http://dx.doi.org/10.1520/JFS2003366

Goray, M., R. J. Mitchell, and R. A. H. van Oorschot. 2010. "Investigation of Secondary Transfer of Skin Cells under Controlled Test Conditions". Legal Medicine, 12(3):117-20. http://dx.doi.org/10.1016/i.legalmed.2010.01.003

Goray, M., R. A. H. van Oorschot, and R. J. Mitchell. 2012. "DNA Transfer with Forensic Exhibit Packaging: Potential for DNA Loss and Re-location". Forensic Science International: Genetics, 6(2):158-66. http://dx.doi.org/10.1016/j.fsigen.2011.03.013

Goray, M., E. Eken, R. J. Mitchell, and R. A. H. van Ooschot. 2010. "Secondary DNA Transfer of Biological Substances under Varying Test Conditions". Forensic Science International: Genetics, 4(2):62-67. http://dx.doi.org/10.1016/j.fsigen.2009.05.001

Harris, David. A. 2012. Failed Evidence. New York, NY: New York University Press.

Hurst, L., \& Lothridge, K. 2010. "2007 DNA Evidence and Offender Analysis Measurement: NA Backlogs, Capacity and Funding". Rockville, MD: National Criminal Justice. Reference Service. Retrieved October 30, 2014 (https://www.ncjrs.gov/pdffiles1/nij/grants/230328.pdf).
Kenna, J., M. Smyth, L. McKenna, C. Dockery, and S. D. McDermott. 2011. "The Recovery and Persistence of Salivary DNA on Human Skin". Journal of Forensic Sciences, 56(1):170-75. http://dx.doi.org/10.1111/i.1556-4029.2010.01520.x

Knecht, J., \& Whitman, J. 2008. "DNA Knowledge Among Victim Service Providers: Results of an Online Survey and a Multidisciplinary Focus Group". Washington: National Center for Victims of Crime.

Korpelainen, Helena and Viivi Virtanen. 2003. "DNA Fingerprinting of Mosses". Journal of Forensic Science, 48(4):804-07.

Krimsky, S., \& Simoncelli, T. 2011. Genetic Justice: DNA Data Banks, Criminal Investigations, and Civil Liberties. New York: Columbia University Press.

Ladd, Carll, Michael Bourke, Michael Adamowicz, Carol A. Scherczinger, and Hentry C. Lee. 1999. "A Systematic Analysis of Secondary DNA Transfer". Journal of Forensic Sciences, 44(6):1270-72.

Lambert, E., Nerbonne, T., Watson, P. L., Buss, J., \& al, e. (2003) ." The forensic science needs of law enforcement applicants and recruits: A survey of Michigan law enforcement agencies." Journal of Criminal Justice Education, 14(1), 6781,181,183-186. Retrieved October 30, 2014 from: http://search.proquest.com/docview/223366142?accountid=3 9173

National Institute of Justice. 1999, September. What every law enforcement officer should know about dna. Retrieved May 30, 2011, from National Institute of Justice: http://www.ncjrs.gov/pdffiles 1/nij/bc000614.pdf

National Institute of Justice. 2003. Dna evidence: What law enforcement officers should know. Retrieved June 1, 2011, from NIJ Journal: https://www.ncjrs.gov/pdffiles1/jr000249c. pdf

National Institute of Justice. 2004. "DNA in 'Minor' Crimes Yields Major Benefits in Public Safety.".In Short, 1-4.

Peterson, J. L. \& Markham, P. N. 1995. "Crime Laboratory Proficiency Testing Results, 1978-91" (Part I). J. Forensic Science, 40:994-1008.

Peterson, J. L. \& Markham, P. N. 1995. "Crime laboratory proficiency testing results, 1978-91" (Part II). J. Forensic Science, 40:1009-29.

Peterson, J., Sommers, I., Baskin, D., \& Johnson, D. 2010. The role and impact of forensic evidence in the criminal justice process. Rockville: NCJRS.

Phipps, M. \& Petricevic, S. 2007. "The Tendency of Individuals to Transfer DNA to Handled Items." Forensic Science International, 162:162-68. http://dx.doi.org/10.1016/j.forsciint.2006.07.010

Reaves, B. A. 2009. State and local law enforcement training academies, 2006. Washington: Bureau of Justice Statistics.

Reaves, B. A. 2011. Census of state and local law enforcement agencies, 2008. U.S. Department of Justice.

Roman, J. K., Reid, S., Reid, J., Chalfin, A., Adams, W., \& Knight, C. 2008. The DNA Field Experiment: Cost-Effectiveness Analysis of the use of DNA in the Investigation of Highvolume Crimes. Washington, DC: The Urban Institute.

Scherczinger, Carol A., Carll Ladd, Michael Bourke, Michael S. Adamowicz, et al. 1999. "A Systematic Analysis of PCR Contamination. "Journal of Forensic Sciences, 44(5):104245

Strom, K. J., \& Hickman, M. J. 2010. "Unanalyzed evidence in lawenforcement agencies: A national examination of forensic processing in police departments". Criminology \& Public Policy, 9(2):381-404. http://dx.doi.org/10.1111/j.1745-9133.2010.00635.x

Strom, K. J., Hickman, M. J., \& Ropero-Miller, J. D. 2011. "Evidence Retention Policies in US Law Enforcement Agencies: Implications for Unresolved Cases and Postconviction DNA 
testing." Journal of Contemporary Criminal Justice, 27(2), 133-148.

http://dx.doi.org/10.1177/1043986211405835

Strom, K. J., Ropero-Miller, J., Jones, S., Sikes, N., Pope, M., \& Horstmann, N. 2009. The 2007 survey of law enforcement forensic evidence processing. Rockville: NCJRS.

Walton, L. M., A. R. Jackson, H. A. Mountain. 2011. "The Potential Impact of Secondary Transfer and Persistence of DNA on Forensic Research." Forensic Science International: Genetics, 3(1):e542. http://dx.doi.org/10.1016/i.fsigss.2011.09.118

Warshauer, D. H., P. Marshall, S. Kelly, J. King and B. Budowie. 2012. "An Evaluation of the Transfer of Saliva-Derived DNA." International Journal of Legal Medicine, 126(6):851-61. http://dx.doi.org/10.1007/s00414-012-0743-1

Washington State Patrol. 2010, March. Forensic services guide. Retrieved October 25, 2011, from Washington State Patrol: http://www.wsp.wa.gov/forensics/docs/bureau/forensic_servic es_guide.pdf

Weiss, Jim and Mickey Davis. 2003. "Managing the Evidence Room". Law and Order, 51(8):92-95.

Wiegand, P., C. Heimbold, R. Klein, U. Immel, D. Stiller, and M. Klintschar. 2010. "Transfer of Biological Stains from Different Surfaces." International Journal of Legal Medicine, 125(5):727-31.

http://dx.doi.org/10.1007/s00414-010-0424-x

WSCJTC. 2012. Law Enforcement Academy. Retrieved March 5, 2012, from Washington State Criminal Justice Training Commission: https://fortress.wa.gov/cjtc/www/index.php? option=com_content\&view=article\&id $=15 \&$ Itemid $=103$

WSCJTC. 2012a. Basic Law Enforcement Academy. Retrieved March 5, 2012, from Washington State Criminal Justice Training Commission: https://fortress.wa.gov/cjtc/www/index. php?option=com_content\&view=article\&id=39\&Itemid=27

Received on 09-10-2014

Accepted on 27-11-2014

Published on 05-12-2014

DOI: http://dx.doi.org/10.6000/1929-4409.2014.03.31

(C) 2014 Hauhart and Menius; Licensee Lifescience Global.

This is an open access article licensed under the terms of the Creative Commons Attribution Non-Commercial License (http://creativecommons.org/licenses/by-nc/3.0/) which permits unrestricted, non-commercial use, distribution and reproduction in any medium, provided the work is properly cited. 